Book Review:

Judul Buku : Penerapan Good Corporate Governance (Mengesampingkan Hak-

Hak Istimewa Demi Kelangsungan Usaha)

Penulis : Indra Surya \& Ivan Yustiavandana

Penerbit : Kencana

Tahun Terbit: 2006

Tebal : xii +243 Halaman

\title{
MENGAWAL PRINSIP-PRINSIP GOOD CORPORATE GOVERNANCE DENGAN PENEGAKAN HUKUM
}

\section{Oleh: Imam Mustofa*}

Buku ini layak menjadi panduan bagi para pemangku kepentingan stakeholder koorporasi yang ingin kepentingannya mendapatkan perlindungan, baik perlindungan dalam jangka panjang maupun jangka pendek. Penulis buku ini memaparkan prinsipprinsip pelaksanaan tata kelola koorperasi yang baik (good corporate governance/ GCG) meliputi etika tata kelola, termasuk etika dan aturan-aturan yang memberikan sanksi tegas. Apa yang disuguhkan di dalam buku ini tidak sekedar etika atau prinsip moral, tetapi juga mencakup aspek hukum secara khusus yang terkait langsung. Di samping itu, penegakkan hukum secara luas yang merupakan komponen penting dalam pelaksanaan GCG juga dipaparkan dalam buku ini.

Ketika etika dipahami sebagai seperangkat prinsip moral yang membedakan apa yang benar dari apa yang salah, maka etika sangat diperlukan dalam aktivitas bisnis seperti dalam perusahaan yang di dalamnya terdapat tata kelola. ${ }^{1}$ Sebagaimana

* Dosen Fak. Hukum Universitas Pekalongan. Email: mostofa@yahoo.com.

1 Menurut Rafiq Issa Beekun, etika dapat didefinisikan sebagai seperangkat prinsip moral yang membedakan yang baik dari yang buruk. Etika adalah bidang ilmu yang bersifat normatif, karena ia berperan menetukan apa yang harus dilakukan atau tidak dilakukan oleh seorang individu. Etika bisnis, kadangkala merujuk pada etika manajemen atau etika organisasi, yang secara sederhana membatasi kerangka acuannya kepada konsepsi sebuah perusahaan (Rafiq Issa Bekun, Islamic Business Ethics”, (Virginia: The International Institute of Islamic Thought, 1997). 
diketahui, bisnis adalah serangkaian peristiwa yang melibatkan pelaku bisnis. Para pelaku bisnis mempunyai kecenderungan untuk melakukan tabrakan kepentingan, saling menghalalkan segala cara dalam memperoleh keuntungan sebanyak mungkin, bahkan saling membunuh, sehingga pelaku bisnis yang kuat semakin mendominasi. Sementara yang lemah terperosok di sudut-sudut ruang bisnis. ${ }^{2}$

Hampir semua kalangan sepakat bahwa penerapan GCG dalam sebuah koorporasi merupakan sebuah keharusan. Namun demikian, pada dasarnya, penerapan prinsip-prinsip GCG merupakan sebuah pilihan. Karena GCG lebih merupakan etika bisnis dibandingkan suatu keharusan dalam penerapannya (mandatory). Lalu bagaimana prinsip-prinsip etik ini akan berjalan efektif pada korporasi-koorporasi di Indonesia, padahal ia tidak mengandung sanksi yang jelas. Oleh karena itu, penerapan GCG perlu pengawal yang tegas, yaitu penegakan hukum secara konsisten dan berkelanjutan.

Dalam mendifinisikan corporate governance, penulis buku ini antara lain mengutip definisi yang diungkapkan oleh komite Cadbury (Cadbury committee) yang merupakan sebuah lembaga yang pertama kali dibentuk oleh Bank of England yang bertugas menyusun corporate governance code. Komite ini mendefinisikan corporate governance sebagai suatu sistem yang mengarahkan dan mengendalikan perusahaan dengan tujuan, agar mencapai keseimbangan antara kekuatan kewenangan yang diperlukan oleh perusahaan untuk menjamin kelangsungan eksistensinya dan pertanggungjawaban kepada stakeholdes. Hal ini berkaitan dengan peraturan kewenangan pemilik, direktur manajer, pemegang saham dan sebagainya. ${ }^{3}$

Mas Achmad Daniri mendefinisikan GCG sebagai "tata kelola perusahaan yang memberikan jaminan berlangsungnya sistem dan proses pengambilan keputusan organ perusahaan berlandaskan pada prinsip keadilan, transparan, bertanggung jawab, dan akuntabel. Dalam proses pengambilan keputusan, organ perusahaan ini juga terkait dengan stakeholders perusahaan, seperti kreditor, pemasok (supplier), masyarakat, konsumen, pemerintah, media dan lembaga swadaya masyarakat."4

2 Muhammad, Etika Bisnis Islami, (Yogyakarta: Akademi Manajemen Perusahaan YKPN, 2002), hal. 41.

3 Indra Surya \& Ivan Yustiavandana, Penerapan Good Corporate Governance (Mengesampingkan Hak-hak Istimewa Demi Kelangsungan Usaha), (Jakarta: Kencana, 2006), hal. 25.

4 Mas Achmad Daniri, Membudayakan 'Good Corporate Governance' http:// www.kompas.com/kompas\%2Dcetak/0404/15/ekonomi/970822.htm, Kamis, 15 April 2004. 
Di Indonesia, secara harfiah, governance kerap diterjemahkan sebagai "pengaturan." Adapun dalam konteks GCG, governance sering juga disebut "tata pamong", atau penadbiran yang terakhir ini, bagi orang awam masih terdengar janggal di telinga. Maklum, istilah itu berasal dari Melayu. Namun tampaknya secara umum di kalangan pebisnis, istilah GCG diartikan tata kelola perusahaan, meskipun masih rancu dengan terminologi manajemen. Masih diperlukan kajian untuk mencari istilah yang tepat dalam bahasan Indonesia yang benar. Kemudian, "GCG" ini didefinisikan sebagai suatu pola hubungan, sistem, dan proses yang digunakan oleh organ perusahaan (BOD, BOC, RUPS) guna memberikan nilai tambah kepada pemegang saham secara berkesinambungan dalam jangka panjang, dengan tetap memperhatikan kepentingan stakeholder lainnya, berlandaskan peraturan perundangan dan norma yang berlaku.

Dengan demikian Good Corporate Governance merupakan:

1. Suatu struktur yang mengatur pola hubungan harmonis tentang peran dewan komisaris, Direksi, Pemegang Saham dan Para Stakeholder lainnya;

2. Suatu sistem pengecekan dan perimbangan kewenangan atas pengendalian perusahaan yang dapat membatasi munculnya dua peluang: pengelolaan yang salah dan penyalahgunaan aset perusahaan;

3. Suatu proses yang transparan atas penentuan tujuan perusahaan, pencapaian, berikut pengukuran kinerjanya.

Stijn Claessens menyatakan bahwa, pengertian tentang corporate governance dapat dimaksudkan dalam dua kategori. Pertama, lebih condong pada pola serangkaian perilaku perusahaan yang diukur melalui kinerja, pertumbuhan, struktur pembiayaan perlakuan terhadap para pemegang saham, dan stakeholders. Kedua, lebih melihat pada kerangka secara normatif, yaitu segala ketentuan hukum, sistem peradilan, pasar keuangan, dan sebagainya yang memperngaruhi perilaku perusahaan ${ }^{5}$.

Terkait dengan prinsip-prinsip GCG, penulis buku ini mengemukakan pendapat Saleem Seikh dan William Rees proses corporate governance meliputi empat prinsip aktivitas: pertama, direction yang berfokus pada formulasi arah strategi untuk masa depan perusahaan dalam jangka panjang; kedua, executive action, yang diaplikasikan dalam pengambilan keputusan; ketiga, pengawasan, yang meliputi monitoring performance dari manajemen; keempat, akuntabilitas yang berfokus pada

5 Indra Surya \& Ivan Yustiavandana, Penerapan Good Corporate ...., hal. 26. 
pertanggungjawaban pihak-pihak yang membuat keputusan. ${ }^{6}$ Menurut Robert I. Tricker, empat hal ini merupakan kegiatan utama corporate governance. ${ }^{7}$

Dalam Keputusan Menteri Negara penanaman Modal Dan BUMN melalui SK No. Keputusan. 23/M-PM. PBUMN/2000 disebutkan bahwa tiga prinsip yang harus dipegang dalam pengelolaan institusi ekonomi di lingkungan BUMN dalam upaya menerapkan GCG adalah transparansi, kemandirian dan akuntabilitas. ${ }^{8}$ Sedangkan Komite nasional Kebijakan GCG menetapkan code for good corporate governance pada Maret 2000 yang terdiri dari transparansi, akuntabilitas, fairness dan kemandirian. ${ }^{9}$

Apa yang diungkapkan oleh penulis buku ini pada dasarnya sejalan dengan pernyataan Emil Salim. Menurutnya, unsur-unsur yang terkandung di dalam good governance itu sendiri meliputi beberapa hal. Pertama, Kewajaran (Fairness) dalam hubungan dengan semua pemegang saham dan kewajaran dalam bertransaksi dengan rekanan. Kedua, Transparansi mengenai keuangan dan operasi perusahaan terhadap pemegang saham dan pemerintah. Ketiga, Akuntabilitas dalam hubungan pertanggungjawaban dewan komisaris dan dewan direksi pada perusahaan. Keempat, Pertanggungjawaban perusahaan dalam melaksanakan peraturan perundangundangan. ${ }^{10}$

Sita Supomo juga pernah menjelaskan prinsip-prinsip GCG di atas. Ia menjelaskan, prinsip responsibility (pertanggung jawaban) mencakup pertanggungjawaban kedalam dan keluar. Pertanggungjawaban kedalam adalah pertanggungjawaban kepada kalangan internal sebuah koorporasi. Sedangkan pertanggungjawaban keluar mencakup pertanggungjawaban kepada masyarakat secara luas. Tiga prinsip GCG lainnya adalah fairness, transparency, dan accountability. Ada perbedaan yang cukup mendasar antara prinsip responsibility dan tiga prinsip GCG lainnya. Tiga prinsip GCG pertama lebih memberikan penekanan terhadap kepentingan pemegang saham perusahaan (shareholders) sehingga ketiga prinsip tersebut lebih mencerminkan shareholders-driven concept. Contohnya, perlakuan

\footnotetext{
${ }^{6} \quad$ Ibid., hal. 28; Lihat juga Saleem Seikh dan William Rees, Corporate Governance \& Corporate Control”, (London: Cavendish Publishing Limited, tt), hal. 5.

Tricker, Robert I., Corporate Governance - Practices, Procedures, and Power in British Companies and Their Board of Directors, (UK, Gower, 1984).

8 Hassel Nogi S. Tangkilisan, Good Corporate Governance, (Yogyakarta: Balairung, 2003), hal. 11.

9 Ibid. hal. 11.

10 Emil Salim, Good Governance Dan Masyarakat Warga, E-Journal Transparans, Edisi 15
} Desember 1999. http:/ /www.transparansi.or.id. (diakses 25/04/2000). 
yang adil terhadap pemegang saham minoritas (fairness), penyajian laporan keuangan yang akurat dan tepat waktu (transparency), dan fungsi dan kewenangan RUPS, accountability $)^{11}$.

Dalam prinsip responsibility, penekanan yang signifikan diberikan pada kepentingan stakeholders perusahaan. Di sini perusahaan diharuskan memperhatikan kepentingan stakeholders perusahaan, menciptakan nilai tambah (value added) dari produk dan jasa bagi stakeholders perusahaan, dan memelihara kesinambungan nilai tambah yang diciptakannya. Karena itu, prinsip responsibility di sini lebih mencerminkan stakeholders-driven concept. ${ }^{12} \mathrm{Jadi}$ penulis buku ini hanya mengulang dan menjelaskan pendapat yang sudah ada, hanya saja lebih sistematis, karena sudah tersusun dalam sebuah buku. Sedangkan penjelasan sebelumnya tercecer dalam makalah-makalah.

Dilihat dari sudut pandang kelembagaan, corporate governance terkait langsung dengan pembuat kebijakan publik karena hukum, regulasi dan institusi yang ada merupakan sumber yang paling penting dalam pembentukan kerangka normatif tata kelola perusahaan (corporate governance framework) di suatu Negara. Peraturan perundang-undangan di bidang pasar modal, perseroan terbatas, perbankan, asuransi, dan kepailitan akan mempengaruhi kebijakan dan perilaku stiapperusahaan. ${ }^{13}$

Kalau dilihat dari isi buku ini, pada dasarnya penulis menekankan betapa pentingnya penegakan hukum dalam sebuah negara agar prinsip-prinsip GCG dapat diimplementasikan. Karena ada kaitan yang erat antara suatu bidang dengan bidang yang lain. GCG tidak hanya terkait dengan kegiatan ekonomi, tetapi juga dengan hukum, politik, budaya dan bidang-bidang yang lain. Pembuat kebijakan publik misalnya, memiliki tanggung jawab untuk memastikan adanya keseimbangan antara peraturan yang dibuatnya dengan perjanjian yang dibuat para pelaku pasar. Hukum dan pelaksanaannya oleh lembahga regulator dan pengadilan merupakan bagian yang sangat esensial bagi terwujudnya good coeporate governance. ${ }^{14}$

Pembangunan pada bidang ekonomi merupakan penggerak utama pembangunan. Namun pembangunan ekonomi ini harus disertai upaya saling

11 Sita Supomo, "Corporate Social Responsibility (CSR) dalam Prinsip GCG" http:// www.republika.co.id/suplemen/cetak_detail.asp?mid=3\&id=176267\&kat_id=105\&kat_id1=149 \&kat $\_$id2=313 (Rabu, 20 Oktober 2004). (diakses 5/08/2005).

12 Ibid.

13 Indra Surya \& Ivan Yustiavandana, Penerapan Good..., hal. 9-10.

14 Ibid., hal. 10. 
memperkuat, terkait serta terpadu dengan pembangunan bidang lainnya. Pembangunan ekonomi dengan hukum mempunyai hubungan timbal balik dan erat. ${ }^{15}$ Berkaitan dengan hal ini Sunarjati Hartono pernah menyatakan:

“.....pembangunan dasar-dasar pemikiran di bidang ekonomi ikut mengubah dan menentukan dasar-dasar sistem hukum yang bersangkutan, maka penegakan asas-asas hukum yang sesuai juga akan memperlancar terbentuknya struktur ekonomi yang dikehendaki, tetapi sebaliknya penegakkan asas-asas hukum yang tidak sesuai justru akan menghambat terciptanya struktur ekonomi yang dicitacitakan." 16

Setelah beberapa hasil pengkajian yang dilakukan lembaga-lembaga riset internasional pasca krisis 1997 menyimpulkan secara eksplisit bahwa masalah tata kelola perusahaan yang buruk (poor corporate governance) merupakan salah satu faktor utama pendorong keruntuhan ekonomi di sejumlah negara termasuk Indonesia. Johnson, boone, Breach dan Friedman dalam penelitiannya membuktikan bahwa pelaksanaan coeporate governance dalam sistem hukum yang lemah menyebabkan dampak krisis ekonomi yang sangat meluas ketika terjadinya krisis ekonomi di Asia. Kualitas pelaksanaan coeporate governance yang lemah menjadi alasan yang kuat bagi terjadinya krisis mata uang dan menurunnya kinerja pasar modal, selain berbagai alasan ekonomi lainnya. ${ }^{17}$

Banyak upaya yang telah dilakukan untuk menyusun, mengelaborasi, dan bahkan menyempurnakan aturan seputar corporate governance yang dituangkan dalam berbagai regulasi. Penegakan hukum, khususnya pelaksanaan hukum kontrak merupakam masalah yang sangat mempengaruhi aspek corporate governance. Defon dan Hung yang telah banyak melakukan studi di berbagai Negara, menemukan bahwa penegakan hukum jauh lebih penting daripada aturan-aturan yang dibuat ketika menjelaskan masalah penggantian CEO perusahaan. Maka wajarlah kalau implementasi GCG di Indonesia menurun, karena penegakan hukum dan pelaksanaan aturan-aturan yang telah dibuat cukup lemah ${ }^{18}$.

Merujuk pada hasil survei Good Corporate Governance 2002 dari Credit Lyonnais SA (CLSA), sebuah perusahaan jasa keuangan global yang bermarkas di Paris,

15 Johannes Ibrahim \& Lindawaty Sewu, Hukum Bisnis dalam Persepsi Manusia Modern, (Bandung: Refika Aditama, 2004), hal. 23.

16 Sunarjati Hartono, Hukum Ekonomi Pembangunan Indonesia, (Bandung: Bina Cipta, 1984). hal. 6-7.

17 Indra Surya \& Ivan Yustiavandana, Penerapan Good Corporate ..., hal. 10.

18 Ibid., hal. 27. 
memberikan penilaian bahwa implementasi GCG di Indonesia mengalami penurunan. Posisi Indonesia jelas tidak berada dalam posisi 20 besar dunia, di bawah posisi Singapura dan Malaysia, dua rekan di Asia Tenggara. Singapura mendapatkan skor 7,4 dan Malaysia mendapatkan skor 4,7. Lalu, Indonesia? Skor yang diberikan 2,9. ${ }^{19}$

Pernyataan Ketua BKPM Theo F Toemion bahwa Indonesia dikenal lemah dalam penerapan governance, baik pada sektor pemerintahan maupun perusahaan, perlu dicamkan, diwaspadai, dan dicermati. Dalam kondisi demikian, kata Toemion, Indonesia tetap saja masih menerima capital inflow yang besar. Nilai dari approved Foreign Direct Investment (FDI) selain masa krisis 1997-1999, masih menunjukkan peningkatan, dari US\$10.9 miliar pada 1999 menjadi US\$14.4 miliar pada 2000 (EIU, Indonesia Country Forecast 2001-2002). Angka yang menunjukkan bahwa kredibilitas mental dan perangkat hukum yang memprihatinkan belum merupakan hambatan yang besar dalam pertumbuhan sektor korporasi. Akan tetapi, efek tersebut mengakumulasi dalam bentuk distorsi yang lain dan pecah dalam bentuk krisis. ${ }^{20}$

Selain berkaitan erat dengan penegakan hukum, pelaksanaan good GCG juga berkaitan dengan iklim politik. Karena antara hukum dan politik sangat berkaitan erat dan saling mempengaruhi. Hal ini senada dengan pendapat Mahfud MD yang mengatakan bahwa produk hukum akan sangat diwarnai atau ditentukan oleh imbangan kekuatan atau konfigurasi politik yang melahirkannya. Asumsi ini dipilah berdasarkan kenyataan bahwa setiap produk hukum merupakan produk keputusan politik sehingga hukum dapat dilihat sebagai kristalisasi dari pemikiran politik yang saling berinteraksi di kalangan para politisi. ${ }^{21}$ Bahkan menurut Daniri komposisi suara pemenang pemilu juga berpengaruh terhadap pelaksanaan GCG. Contohnya pemilu tahun 1999 yang tidak menghasilkan partai pemenang mutlak, kadang terpaksa terjadi kebijakan pemerintah yang kompromistis. Semua ini jelas kurang mendukung percepatan pelaksanaan GCG di Indonesia, berbeda dengan di negaranegara lain di kawasan Asia sehingga kemajuan pelaksanaan GCG mereka melaju lebih cepat dibandingkan kita.

David Vogel, penyandang Solomon Lee Professor of Business Ethics pada Haas School of Business sekaligus Professor of Political Science pada University of California

19 Mas Ahmad Daniri, Membudayakan 'Good Corporate Governance...'.

20 Ubaidillah Nugraha, Bad Corporate Governance, Kasus Amerika Serikat dan Indonesia" http://www.freelists.org/cgi-bin/list?list_id=untirtanet. 2002, (diakses 23/04/2003).

21 Moh Mahfud MD. Pergulatan Politik dan Hukum di Indonesia (Yogyakarta: Gama Media, 1999), hal. 4. 
Berkeley, dalam bukunya "Trading Up" membahas mengenai regulasi lingkungan serta Kindred Strangers tentang hubungan yang erat antara bisnis dan politik. ${ }^{22}$

Menurut Emil Salim, dalam pelaksanaannya, good governance mengandalkan rule of Law terutama yang mencakup bidang ekonomi dan politik, penentuan kebijakan yang transparan, pelaksanaan kebijakan yang accountable, birokrasi yang berkualitas dan juga masyarakat yang capable. Elemen-elemen accountability (political dan publik), adanya kerangka hukum dalam pembangunan yang menjelaskan prediktibilitas abdi negara terhadap sektor swasta, informasi mengenai kebijakan pemerintah yang terjangkau oleh publik dan transparan berisikan kebijakan terbuka untuk pengawasan yang sangat berkaitan dengan Convenant on civil and political rights dan convenant on economic, social, and cultural rights. Good governance pun mempunyai inti, yaitu mempromosikan demokrasi, aturan hukum dan juga hak asasi manusia berdasarkan pemikiran bahwa pasa dan pemerintah hanya dapat berfungsi efisien jika dikontrol oleh pemberi suara. ${ }^{23}$ Salah satu poin pedoman pelaksanaan GCG menyebutkan tentang pentingnya menciptakan sistem politik yang sehat dengan penyelenggara negara yang memiliki integritas dan profesionalitas yang tinggi. ${ }^{24}$

Lalu bagaimana korelasi antara kepentingan stakeholder perusahaan terhadap implementasi prinsip-prinsip GCG? Bagaimana pula mekanisme yang ditawarkan oleh prinsip-prinsip tersebut dalam memenuhi kepentingan stakeholder perusahaan.

Sebelum menjawab pertanyaan di atas, terlebih dahulu penulis buku ini menjelaskan siapa yang dimaksud stakeholder perusahaan. Stakeholder perusahaan adalah setiap pihak, baik individu maupun kelompok yang dapat terkait atau berpengaruh terhadap aktivitas perusahaan. Secara teoritis stakeholder perusahaan dapat dibagi mejadi dua, yaitu:

1. Primary stakeholder, yaitu para pemegang saham, investor, karyawan dan manager, rekanan bisnis, dan masyarakat;

2. Scondary stakeholder, yaitu pemerintah, institusi bisnis, kelompok social kemasyarakatan, akademisi danpesaing. ${ }^{25}$

22 Gatot Arya Putra (2006), Beretorika untuk Kemiskinan, http://www.kompas.com/kompascetak/0609/01/teropong/2921526.htm. Jumat, 01 September 2006.

23 Emil Salim, Good Governance dan Masyarakat Warga....

24 _EDITO_COMEFROMKomisi Pemberantasan Korupsi Republik Indonesia : http:// www.kpk.go.id/modules/edito/content.php?id=27 (diakses 14/04/2005).

25 Good Corporate Governance (http//www.sdp.-consulting.com/history.htm) diakses Juni 2007. 
Pada dasarnya, pembuatan prinsip-prinsip GCG memiliki tujuan untuk menciptakan hubungan yang harmonis antara pemegang saham, pengurus, pihak kreditor, pemerintah, karyawan serta kepentingan internal dan eksternal lainnya sehubungan dengan hak dan kewajiban mereka. Secara umum, penerapan GCG secara konkret, memiliki tujuan terhadap perusahaan sebagai berikut:

1. Memudahkan akses terhadap investasi domestik maupun asing;

2. Mendapatkan cost capital yang lebih murah;

3. Memberikan keputusan yang lebih baik dalam meningkatkan kinerja ekonomi perusahaan;

4. Meningkatkan keyakinan dan kepercayaan dari stakeholder terhadap perusahaan;

5. Melindungi direksi dan komisaris dari tuntutan hukum. ${ }^{26}$

Sebagaimana telah disebutkan di atas, bahwa stakeholder perusahaan terbagi menjadi primary stakeholder dan secondary stakeholder. Prinsip-prinsip GCG dituntut dapat memenuhi dan melindungi kepentingan mereka, namun secara umum yang harus diprioritaskan adalah kepentingan primary stakeholder.

Prinsip-prinsip GCG (fairness, transparency, accountability dan responsibility) apabila diterapkan dengan sebaik-baiknya maka akan dapat menjamin hak serta melindungi kepentingan semua stakeholder perusahaan. Bagi para pemegang saham misalnya, kepentingan mendasar selain mendapatkan keuntungan adalah mendapat perlakuan dan perlindungan yang seimbang dari perusahaan, baik pemegang saham mayoritas maupun minoritas. Kepentingan ini dapat dipenuhi dengan prinsip GCG yang pertama, yaitu fairness yang menyatakan keharusan bagi perusahaan untuk memberikan kedudukan yang sama bagi para pemegang saham. ${ }^{27}$

Contoh lain adalah kepentingan keterbukaan untuk mendapatkan informasi material perusahaan. Untuk memenuhi kepentingan ini, prinsip kedua dari GCG yang dapat diimplementasikan, yaitu prinsip transparansi yang merupakan salah satu prinsip tertua dalam bidang hukum perusahaan. Transparansi informasi ini tidak bersifat absolut, karena tetap ada pembatasan-pembatasan mengenai informasi apa saja yang dapat diberikan. Kemudian terkait dengan munculnya konflik antara dewan direksi yang secara langsung menjadi agen bagi para pemegang saham dalam menjalankan perusahaan, dengan para pemegang saham itu sendiri atau dengan 
para stakeholder lain. Untuk menyelesaikan permasalahan semacam ini dapat diterapkan prinsip ketiga, yaitu prinsip akuntabilitas (accountability) yang didasarkan pada sistem internal checks and balances yang mencakup praktik audit yang sehat. Akuntabilitas dapat dicapai dengan pengawasan efektif yang didasarkan pada keseimbangan kewenangan antara pemegang saham, komisaris dan direksi. ${ }^{28}$

Kepentingan masyarakat sebagai konsumen yang utama adalah mendapatkan produk barang dan jasa yang baik dengan harga yang pantas. Bukan hanya itu, masyarakat sebagai konsumen harus mendapatkan perlindungan yang layak. ${ }^{29}$ Prisnsip GCG dapat diimplementasikan untuk memenuhi kepentingan ini adalah prinsip responsibilitas yang merupakan wujud pertanggungjawaban dari suatu perusahaan untuk mematuhi dan menjalankan setiap aturan yang telah ditentukan oleh peraturan perundang-undangan yang berlaku.

Terkait dengan kepentingan publik ini akan sangat lebih mendukung kelangsungan sebuah perusahaan apabila perusahaan melaksanakan tanggung jawab sosialnya corporate social responsibility (CSR). Karena CSR dalam prinsip good coorporate government (GCG) ibarat dua sisi mata uang. Keduanya sama penting dan tidak terpisahkan. CSR ini merupakan salah satu bentuk pertanggungjawaban dalam sebuah koorporasi.

Dalam gagasan CSR, perusahaan tidak lagi dihadapkan pada tanggung jawab yang berpijak pada single bottom line, yaitu nilai perusahaan (corporate value) yang direfleksikan dalam kondisi keuangannya (financial) saja. Tanggung jawab perusahaan harus berpijak pada triple bottom lines. Di sini bottom lines lainnya, selain finansial adalah sosial dan lingkungan. Kondisi keuangan saja tidak cukup menjamin nilai perusahaan tumbuh secara berkelanjutan (sustainable). Keberlanjutan perusahaan hanya akan terjamin apabila perusahaan memperhatikan dimensi sosial dan lingkungan hidup. Sudah menjadi fakta bagaimana resistensi masyarakat sekitar muncul ke permukaan terhadap perusahaan yang dianggap tidak memperhatikan lingkungan hidup. Contohnya kasus Indorayon di Sumatera Utara. ${ }^{30}$

28 Ibid., hal. 76-77.

29 Untuk di Indonesia, Perlindungan konsumen merupakan hal yang baru, khususnya dalam dunia pertauran perundang-undangan. Padahal desakan untuk mengeluarkan peraturan ini sudah cukup lama disusrakan. Undang-undang perlindungan konsumen baru dikeluarkan Pemerintah Republik Indonesia pada 20 April 1999. (Gunawan Widjaja \& Ahmad Yani, Hukum tentang Perlindungan Konsumen, (Jakarta: PT. Gramedia, 2003), hal. 1-2.

30 Sita Supomo, Corporate Social Responsibolity (CSR), Ibid. 
Dari penjelasan di atas, dapat dinyatakan bahwa prinsip GCG memiliki korelasi yang kuat dengan kepentingan semua pihak yang terlibat didalamnya, termasuk kreditor. Bahkan dapat dikatakan bahwa prinsip-prinsip GCG adalah penopangutama pemenuhan beragam kepantingan para stakeholder sebuah korporasi atau perusahaan.

Kepentingan perusahaan pada dasarnya merupakan kompromi dari kepentingan seluruh anggota stakeholders. Peranan implementasi prinsip GCG adalah untuk memberikan mekanisme dan pedoman dalam memberikan keseimbangan bagi para satkeholders dalam memenuhi kepentingannya masing-masing. Apabila kepentingan para anggota stakeholders dapat terpenuhi secara maksimal, tanpa harus merugikan kepentingan stakeholders lainnya, maka titik ekuilibrium tercapai pada saat itu, kepentingan perusahaan akan terumuskan dengan utuh.

Pada bagian ketiga, penulis buku ini menjelaskan kerangka hukum nasional yang terkait dengan implementasi GCG di Indonesia. Bagian ini mendeskripsikan tentang prinsip-prinsip GCG dalam Undang-undang Perseroan Terbatas, BUMN, Perbankan dan Pasar Modal. Selanjutnya menjelaskan secara detail beberapa contoh pelaksanaan GCG di Indonesia. Sebagai contoh koorporasi yang sukses dalam melaksanakan GCG penulis antara lain menyebutkan PT. Astra Tbk, Bank Niaga Tbk, PT. Dankos Laboratories Tbk, Royal Ahold dan Air liquide. Sedangkan sebagai contoh koorporasi yang melanggar prinsip-prinsip GCG antar lain kasus PT. Kopitme Dot Com Tbk, kasus PT. Jakarta International Hotels \& Development Tbk, kasus Litter of Credit BNI 46 dan kasus Penutupan PT. Bank Global Tbk.

Terlepas dari berbagai contoh yang dikemukakan oleh penulis buku ini, secara umum pelaksanaan GCG di Indonesia masih jauh dari harapan. Dalam dunia bisnis, praktik yang melanggar kaidah good governance bukan merupakan suatu isu baru. Meminjam analogi berpikir dari Professor Krugman, terdapat beberapa strategi korporasi di Indonesia yang menyimpang dan sudah menjadi rahasia umum. Dengan melakukan penyuapan kepada pejabat negara, suatu korporasi dapat memperoleh proyek tanpa melalui proses tender. Kalaupun harus tender, pemenangnya adalah korporasi yang telah membayar 'upeti' paling besar. Akibatnya adalah negara harus membayar suatu proyek yang harganya sudah mencakup biaya 'upeti' dan margin keuntungan, yang seringkali tidak rasional. ${ }^{31}$ Praktik perdagangan

31 Ubaidillah Nugraha, Bad Corporate....., Ibid. 
yang tidak sehat banyak bermunculan, terutama karena penguasa sering memberikan perlindungan ataupun privileges kepada para pelaku bisnis tertentu, sebagai bagian dari praktik-praktik kolusi, korupsi, kroni dan nepotisme. ${ }^{32}$

Sejarah Inggris pernah menorehkan kejayaan sektor industri pada tahun 1760 . Hal ini terjadi karena para pengusaha mendapat kebebasan dari landasan kaidahkaidah hukum yang berlaku, sehingga mereka dapat mengejar keuntungan sebesarbesarnya dan mendapat tenaga yang murah. Namun di satu sisi kehidupan pare pekerja sangat memprihatinkan. Para pengusaha tidak memperhatikan kesejahteraan para pegawai, terutama buruh anak-anak dengan menyamakan jam kerja dengan orang dewasa. Namun para kaum intelektual, antara lain Sir Robert Peel dan Robert Own memperjuangkan aturan hukum yang dapat melindungi semua elemen yang terlibat dalam sebuah perusahaan. Perjuang mereka ini menghasilkan "Factory Laws" yang merupakan bentuk pertama campur tangan pemerintah dalam kehidupan perekonomian setelah Adam Smith. ${ }^{33}$ Hal ini menunjukkan betapa pentingnya atauran-aturan hukum dalam aktivitas bisnis, khususnya perusahaan.

Implementasi prinsip GCG secara efektif memerlukan hukum sebagai sarana untuk mendorong ditaatinya nilai-nilai etis tersebut dalam dunia bisnis. Dalam melindungi berbagai pihak yang terkait (stakeholder) diperlukan penegakan hukum (law enforcement) dan regulasi yang terkait dengan implementasi prinsip-prinsip GCG ini secara privat (perdata) dan publik. ${ }^{34}$

Pada dasarnya kerangka hukum dan perundang-undangan di Indonesia telah mengadopsi prinsip-prinsip GCG, baik secara langsung maupun secara tersirat. Yang sangat dibutuhkan sekarang adalah peran dari institusi publik, seperti pengadilan, badan Pangawas Pasar Modal (BAPEPAM), Self Regulatory Organization, Bank Indonesia maupun Kejaksaan, Kepolisisan serta lembaga-lembaga lainnya dalam kerangka hukum nasional sebagai pelaku enforcement hukum dan regulator. Lembaga-lembaga tersebut memegang peranan yang sangat signifikan dalam memberikan perlindungan hukum kuatnya institusi-institusi tersebut tentunya akan semakin mendorong ditaatinya prinsip-prinsip GCG, yang pada gilirannya akan lebih memberikan perlindungan kepada para stakeholder; investor, pemegang saham dan masyarakat.

32 Rachmadi Usman, Hukum Persaingan Usaha di Indonesia, (Jakarta: PT. Gramedia, 2004). hal. 1.

33 Edi Sopandi, Beberapa Hal dan Catatan Berupa Tanya Jawab Hukum Bisnis, (Bandung: Refika Aditama, 2003), hal. 3.

34 Indra Surya \& Ivan Yustiavandana, Penerapan Good Corporate..., hal. 125. 
Peraturan dan perundang-undangan yang sudah dibuat dengan susah payah seringkali dinafikan dan diabaikan, sehingga hukum sangat sulit untuk ditegakan. Padahal dalam kaitannya dengan dunia koorporasi dan bisnis, penegakan hukum merupakan pilar utama yang menopang kelangsungannya. Dalam dunia bisnis, lemahnya penegakan hukum menyebabkan lemahnya perlindungan hak milik pribadi, yang akhirnya akan berpengaruh juga pada sikap dari para investor dan pemegang saham. Salah satu pengaruh signifikannya adalah melalui control dan ownership perusahaan-perusahaan dimana para investor dan pemegang saham berusaha meningkatkan kepemilikan saham pada perusahaan-perusahaan di Indonesia. Lemahnya perlindungan terhadap hak milik inilah yang akhirnya akan mendorong dominannya bisnis group keluarga di Indonesia. Oleh karena itu sekali lagi penulis tegaskan tentang perlunya pengawalan penegakan hukum yang tegas, konsisten dan berkelanjutan dalam pelaksanaan GCG di Indonesia.

\section{DAFTAR PUSTAKA}

Bekun, Rafiq Issa. 1997. Islamic Business Ethics”. Virginia: The International Institute of Islamic Thought.

Daniri, Mas Achmad.2004. Membudayakan 'Good Corporate Governance' http:// www.kompas.com/kompas\%2Dcetak/0404/15/ekonomi/970822.htm, Kamis, 15 April 2004.

EDITO_COMEFROMKomisi Pemberantasan Korupsi Republik Indonesia : http:/ /www.kpk.go.id/modules/edito/content.php?id=27 (diakses 14/04/2005).

Good Corporate Governance (http//www.sdp.-consulting.com/history.htm) diakses Juni 2007.

Hartono, Sunarjati. 1982. Hukum Ekonomi Pembangunan Indonesia. Bandung: Bina Cipta.

Ibrahim, Johannes \& Lindawaty Sewu. 2004. Hukum Bisnis dalam Persepsi Manusia Modern. Bandung: Refika Aditama.

MD., Moh Mahfud. 1999. Pergulatan Politik dan Hukum di Indonesia. Yogyakarta: Gama Media.

Muhammad. 2002. Etika Bisnis Islami, Yogyakarta: Akademi Manajemen Perusahaan YKPN. 
Nugraha, Ubaidillah. 2002. Bad Corporate Governance, Kasus Amerika Serikat dan Indonesia" http://www.freelists.org/cgi-bin/list?list_id=untirtanet. (diakses 23/04/2003).

Putra, Gatot Arya. 2006. Beretorika untuk Kemiskinan, http://www.kompas.com/ kompas-cetak/0609/01/teropong/2921526.htm. Jumat, 01 September 2006.

Salim, Emil. 1999. Good Governance Dan Masyarakat Warga, E-Journal Transparans, Edisi 15 Desember 1999. http://www.transparansi.or.id. diakses 25/04/2000

Seikh, Saleem dan William Rees. Tt. Corporate Governance \& Corporate Control". London: Cavendish Publishing Limited.

Sopandi, Edi. 2003. Beberapa Hal dan Catatan Berupa Tanya Jawab Hukum Bisnis. Bandung: Refika Aditama.

Supomo, Sita. 2004. “Corporate Social Responsibility (CSR) dalam Prinsip GCG” http:// www.republika.co.id/suplemen/cetak_detail.asp?mid= 3\&id=176267\&kat_id= 105\&kat_id1=149\&kat_id2=313 (Rabu, 20 Oktober 2004). (diakses 5/08/2005)

Surya, Indra \& Ivan Yustiavandana. 2006. Penerapan Good Corporate Governance (Mengesampingkan Hak-hak Istimewa Demi Kelangsungan Usaha). Jakarta: Kencana.

Tangkilisan, Hassel Nogi S. 2003. Good Corporate Governance. Yogyakarta: Balairung. Tricker, Robert I. 1984. Corporate Governance - Practices, Procedures, and Power in British Companies and Their Board of Directors. UK: Gower.

Usman, Rachmadi. 2004. Hukum Persaingan Usaha di Indonesia. Jakarta: PT. Gramedia.

Widjaja, Gunawan \& Ahmad Yani. 2003. Hukum tentang Perlindungan Konsumen. Jakarta: PT. Gramedia. 